\title{
Article
}

\section{In whose interest? Exploring care ethics within transformative learning}

Kempster, Steve and Smith, Susan

Available at http://clok.uclan.ac.uk/25795/

Kempster, Steve and Smith, Susan ORCID: 0000-0002-3152-2149 (2019) In whose interest? Exploring care ethics within transformative learning. Management Learning, 50 (3). pp. 302-318. ISSN 1350-5076

It is advisable to refer to the publisher's version if you intend to cite from the work. http://dx.doi.org/10.1177/1350507618822316

For more information about UCLan's research in this area go to http://www.uclan.ac.uk/researchgroups/ and search for < name of research Group>.

For information about Research generally at UCLan please go to http://www.uclan.ac.uk/research/

All outputs in CLoK are protected by Intellectual Property Rights law, including Copyright law. Copyright, IPR and Moral Rights for the works on this site are retained by the individual authors and/or other copyright owners. Terms and conditions for use of this material are defined in the policies page.

\section{CLoK}

Central Lancashire online Knowledge www.clok.uclan.ac.uk

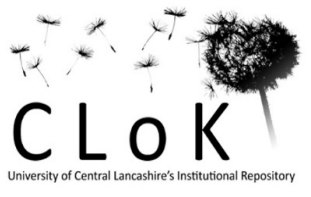




\title{
In whose interest? Exploring care ethics within transformative learning
}

\author{
Abstract \\ This article brings attention to a seemingly pervasive and underlying assumption in critical \\ management education that transformative learning is a good thing. We explore this \\ assumption through a series of narratives examining the ethics of educators overtly seeking \\ to enable transformative learning with owner-managers in order to impact on their \\ businesses. The focus on owner-managers is of significance in terms of transformative \\ learning because of the centrality of the owner-manager to the delicate ecosystem that is \\ the small and medium business. The article makes salient relational care in critical \\ management education and the need for educators to engage in a moral dialogue regarding \\ the relational impact of transformative learning in pedagogic designs. Such dialogue \\ necessitates addressing in whose interest is transformative learning being sought, along \\ with the orientation and framing of such learning.
}

Key words: transformative learning; care ethics, owner-managers; narratives; reflexive dialogue

\section{'On average, it's one divorce per cohort'}

In this article we examine the role of care ethics within transformative learning. We suggest that there is an underlying assumption within management education (ME) and critical management education (CME) that transformative learning is a good thing. There has been a dearth of research in critically examining this assumption. We have searched and struggled to find an in-depth discussion that questions this assumption (questions are raised by Courtenay, Merriam, Reeves and Baumgartner, 2000; and Baumgartner, 2001, 
but without exploration). In major part critical management educators and non-critical management educators, have been following the good thing assumption, despite reference between us of a divorce per cohort occurring within an executive education programme (hereafter to be imaginatively called 'the Programme'). We designed and delivered, as well as facilitated the Programme in our own institution. In addition, we trained 15 executive education providers to deliver the Programme to in excess of 3000 ownermanagers throughout the UK. The Programme utilised cohort sizes ranging between 15-25 owner-managers of small and medium-sized enterprises (SMEs) over a period of 10-12 months. It has been the overt intent of the Programme to catalyse transformative learning (Mezirow, 1981) through reflection, peer learning, group work and opportunities for the owner-managers to practise their learning in the organizational context (for a more detailed overview of the Programme, see Howorth, Smith and Parkinson, 2012).

By transformative learning, we are speaking of the 'gradual or sudden, powerful experiences [that] change the way people see themselves and their world' (Baumgartner, 2001: 16). When we speak of transformative learning within this paper, we are focusing on a critical management education pedagogy. By this, we mean a pedagogy that is aligned to the ideas of emancipation that draws on critical theory ( see Freire, 1970; Alvesson and Wilmott, 1992) - in order to engender reflexivity in managers and thus enable them to stimulate liberating practices (Fenwick 2005). The pedagogy we sought to establish in the Programme was intended to encourage the owner-managers to see afresh the 'restrictive traditions, ideologies and assumptions, power relations and identity formations that inhibit or distort opportunities for autonomy, clarification of genuine needs and wants, and thus greater and lasting satisfaction' (Alvesson and Wilmott, 1992: 92). The focus of the Programme has remained as the educator's ethic on 'defining the extent to which we act 'properly' or 'appropriately' in terms of our responsibilities to challenge thinking' 
(Fenwick, 2005: 46). This seems, on the face of it, a good thing. However, Reynolds (1999) made salient the shadow side of ME that embraces a critical orientation, recommending caution in its application. Little attention has been paid to this shadow side in recent debates on management education (ME). Our contribution is to return to this caution and bring attention to the gap in research regarding the ethics of educationalists pursuing a pedagogy of emancipation that seeks to enable a learner to restructure how they see and act in the world. In particular, we examine the care ethics associated with a transformative-learning pedagogy. We focus on care ethics, rather than, for example, utilitarian or deontological ethics for two reasons: first, that we were struck by anecdotal evidence that the Programme had generated many changes in people and their relationships with others; and second, with care ethics being focused on relationships and connectedness, and consideration to the harm that may occur through actions across such relationships, it resonated strongly with the situation we had experienced in the Programme. That situation being that we, as educationalists, had not actively considered care ethics in the pursuit of transformative learning.

There were four stakeholder interests that the Programme addressed: develop the owner-manager, improve the business for the owners and the employees, enrich society and generate economic wealth, and create a sense of achievement for the educators in undertaking worthwhile work (as well as the remuneration for such activity). On the one hand, these seem unproblematic. All four interests can produce positive outcomes and, in major part, when joined together these interests provide sources for the prevailing positive evaluation of the Programme (Wren and Jones, 2012). On the other hand, a destabilising narrative can emerge for participants on the Programme (Larsson and Holmberg, 2015). We have witnessed accounts from our own participants, along with stories from the other educators who have run the Programme, of such destabilization. Recurring outcomes 
include closing down the business, setting up a new business, impact on family life and, in many instances, divorce.

Transformative learning seeks to stimulate a learner's questioning of underlying assumptions and also to restructure the way the learner sees the world and acts within it (Laros, Fuhr and Taylor, 2017). ME that seeks to pursue and generate such transformative learning opens up questions regarding the care ethics associated with the relational impact of such education. There has been a dearth of attention to the consequences of participants embracing this critical orientation in management education (save for Reynolds 1999; Perriton and Reynolds, 2004; and Fenwick, 2005). When we speak here of ethics, we are considering duty of care and drawing on relational care ethics as the "compelling moral salience of [educationalists] attending to and meeting the needs of [participants] in ME for whom we take responsibility' (Held, 2006: 10). Prominence is given to care as the moral concern; the related question, 'What ought I do?', is answered with the right action, that being one that demonstrates characteristics of care. One such action would be to pay attention to how people are dependent on one another and, as a consequence, to give due consideration to how people are impacted by decisions, and how such people can be safeguarded from harm. Relational care ethics, then, is oriented to the particularities of the situation. Within the context of management education, moral judgements should centre on the care needs of those impacted through a transformative learning pedagogy, with attention to the contexts in which they are situated (Metz and Miller, 2016). The research question that guides our exploration is, 'How might educators address care ethics when seeking to engender transformative learning within management education?'

The paper is structured as follows. First, we examine transformative learning through the lens of care ethics and question the underlying assumption that transformative learning is a desirable end. We next situate our discussion within the context of owner- 
managers and provide details of the Programme. We outline the ethnographic data collection, and the co-constructed auto-ethnographic approach to analysing the data. Emergent from undertaking this hyper-reflexive questioning of our assumptions is a tension between the ethic of emancipatory pedagogy and care ethics. We illustrate and analyse this tension using three narratives that draw on the metaphors of cheating the process, coercion and confessional. We discuss in whose interest is transformative learning. We consider whether educators should more carefully delineate the scope and breadth of such learning. Finally, we explore the applicability of care ethics through Cunliffe's (2008) notion of relational knowing between educators, and with participants regarding the relational impact of transformative learning.

\section{Transformative learning - a good thing?}

To address whether transformative learning is a good thing, we first describe the lens through which we shall view it: care ethics. Care ethics was first given prominence through the work of Gilligan (1982). Her work highlighted, through attention to voice, the significance of connectedness and relationships: 'People live in connection with one another; human lives are interwoven in a myriad of subtle and not so subtle ways' (Gilligan, 1995: 12). Care ethics focuses on 'two kinds of consequences: the extent to which people might be hurt by a particular decision and the degree to which a particular decision might diminish the sense of connectedness among participants in a particular situation' (Hinman, 2008: 386). How these two aspects might be determined draws on intersubjectivity. For example, the consequences of action are understood through talking with people and 'allowing them to participate actively in the process' (2008: 386). Care ethics gives significance to the emotions - particularly compassion and empathy - of the person or people affected. In this way, care ethics engenders a direct personal and connected intersubjective association and attachment. Multiple voices are respected and 
attended to, and no voices should be repressed (Spiller, Erakovic, Henare and Pio, 2011). Care ethics does not assume an independent autonomous moral agent who is detached and able to make a rational judgement of right or wrong drawn from universal principles (Gilligan, 1995: 121). It is a relativistic ethical perspective situated within relationships. It brings attention to unequal relationships and power asymmetries, and the need to be cognisant of the same within relationships. 'All people are vulnerable, dependent and finite, and we all have to find ways of dealing with this in our ... individual and collective behaviour' (Sevenhuijsen, 1998: 28). As such, it offers us a particularly relevant lens through which to view transformative learning within management education. The good thing, then, is to give attention to minimising hurt and maintaining connectedness to those impacted by critical management education - within the Programme and beyond.

The focus of transformative learning is on 'reconstruct[ing] basic assumptions and expectations that frame thinking, feeling and acting' (Laros et al, 2017: ix). 'It is considered to be a "cognitive event", but also a social construct produced and changed in social interaction' (2017: ix). The concept of transformative learning arose from radical education (Freire, 1970) and the notion of conscientization - where people raise their sense of consciousness about their situations (Dunn, 2011, examining Freire, 1970). Mezirow (2003: 58) oriented such consciousness toward a psychoanalytic perspective, as exploring 'habits of mind, meaning perspectives [and] mindsets to create opportunity for being more discriminatory, openly reflective and emotionally able to change'. Adaptations of transformative learning have moved toward a cultural orientation, where concerns extend from the individual, centric position, to an on-going appreciation of 'connections between individuals and social structures' (Tisdell, 2005: 25).

Advocates for transformative learning emphasise that 'dialogue, discourse, or relationships with others' are central aspects (Cranton and Roy, 2003: 91). Taylor (2017: 
21) suggests the educator gives attention to relational enquiry, in which 'the learner [shares] stories of experience and [develops] new stories in the process.' In this way, facilitation seeks to set up 'exposure to alternative perspectives and participation in critical discourse with others to verify one's new reality' (Mezirow, 1990: 364). The accent on change arises from the educator drawing the learner into critical reflection enabled through dialogue, encouraging the learner not simply to think differently, but to act differently (Mezirow, 2000: 24). Brookfield (2000: 125) argues that the distinguishing aspect separating critical reflection, 'a necessary but not sufficient condition', from transformative learning, is the latter's accent on the idea that 'transformation is a transformation in perspective, in a frame of reference ... in a habit of mind' (2000: 139). Engendering transformative learning thus has two significant care ethics implications for educators: first to the learner, where the challenge to deeply held beliefs can be disturbing and unsettling (Dunn, 2011); second, and as a consequence of such individual disturbance, is the systemic impact in terms of relational reach beyond the context of the educational arena emerging out of a learner's new habit of mind and new way of acting. In this way, a pedagogy focused on enabling transformative learning might be better described as a 'pedagogy of the unknowable' (Ellsworth, 1989: 318), where the outcomes cannot be 'known in the sense of being defined, [and are] delineated at a level of determination never accorded to the knower' (1989: 321).

Without conscious attention to care ethics, educators can accidentally act tyrannically when seeking transformative learning, where there is the 'exercise of power beyond right [and not necessarily] for the good of those who are under it' (Hiley, 1987: 346). Ferreday and Hodgson (2008) take a more relational view, examining the complex demands put upon students when educators attempt to engage in transformative learning. These authors give voice to the need for circumspection in terms of relational engagement 
and for transparency with regard to enabling disclosure. There may be pressure within the educational context to reveal personal insights or to be drawn into dialogue beyond boundaries of personal censorship either of which may generate a legacy of regret afterwards. In the process of educators seeking to engender transformative learning, there is much potential to accentuate relational ethical conflicts and harm; this may substantially outweigh the developmental gain, particularly when considering the impact on relationships beyond the peer-learning community.

Although Baumgartner (2001: 21) raised the ethical question of the right to encourage transformative learning, there is no in-depth examination of how educationalists consider care ethics in terms of the duty of care and limiting harm. In a recent comprehensive review of transformative learning (Laros et al, 2017), there is no attention to ethics other than mention of codes of practice for how educators should act in the classroom. The pervading assumption (to which we have also been complicit) is much more to notions of educator as 'facilitator of reasoning in a learning situation and a cultural activist fostering the social, economic and political conditions for freer participation in critical reflection' (Mezirow, 2003: 63).

In the context of CME, Reynolds (2000) has cautioned that peer-learning communities underpinned with participatory approaches may not be the idylls to which educators should necessarily aspire; he highlights the disruptive effect of critical reflection. Furthermore, he signals the necessity of educators helping learners manage processes of discrimination of revised perspectives and assisting them to integrate these into the milieu of contexts. We interpret such discrimination as the need to give reflexive attention to an ethic of care and also consider the scope of impact from transformative learning beyond the classroom. We suggest an appreciation of the context of the participants, in terms of 
the social relationships in which they are embedded, should be central to educators' care ethics.

\section{Owner-managers and transformative learning}

Potentially, owner-managers are susceptible to the tensions and possible tyranny of a transformative pedagogy; they are less able to be circumspect and discriminatory around emerging and revised perspectives within peer-learning dynamics. This is because the sense of community is more significant, due to the perceived felt isolation of the SME owner-manager (Smith and Peters, 2006; Barnes, Kempster and Smith, 2015); the desire to be part of a supportive and developmental community makes them vulnerable to a pedagogy seeking to use the influence of the community (educators and fellow owner-managers) to enable transformative learning. In this context, the educator's care ethics would be most attentive not just to the owner-manager, but also to the business community of which owner-managers are a critical and central aspect. A delicate ecosystem exists between the owner-manager and the respective SME - the enterprise is often seen as being inextricably linked to the owner-manager (Cope, Kempster and Parry, 2011). Gibb (2009) asserts how owner-manager learning is a dynamic rooted in the porosity of them and their businesses. Employees are often recruited from local communities in which the SME is embedded, and may be dependent on the business in certain locations as a consequence of limited employment choices (Barber, Wesson, Roberson and Taylor, 1999). The structural relationship between the owner-manager and the employees engaged therein has emerged through a history of interactions and events, generating a web of power relations that typically centre on the owner-manager (Gibb, 2009). The relational ecosystem that is centred on the owner-manager is also connected to customers and suppliers, many of whom are often found in close proximity to the communities in which the SME is embedded. Thus, we assert that transformative learning centred on the owner-manager has 
the potential for considerable relational reach and impact. As a consequence, the question that guided our research was: 'How should educators address care ethics when seeking to engender transformative learning in the context of owner-manager education?'

\section{Methodology}

Our research endeavoured to explore the learning processes on the Programme: how and where the participants were learning. A qualitative study was conceived in order to understand the meanings and nuances associated with the learning experiences. Many writers on qualitative research comment that researchers adopting a qualitative perspective are concerned with understanding the individual's perceptions of the world (Bell, 1999: 7), with a philosophical position towards a reflection of an interpretivist and constructionist position (Bryman and Bell, 2003). The study took place with one cohort of 25 ownermanagers, from the commencement of the Programme through to the finish, a 12-month period. At the outset, all owner-managers were invited to participate in this research and all 25 agreed, with written permission gained from them all. Profiles of the ownermanagers are outlined in Table 1.

Insert Table 1 about here

\section{Data collection}

An ethnography (physical and online) was carried out by [first author] as Programme director and facilitator throughout the entirety of the Programme. It included participant observation of the physical-learning interventions and online discussion forum (as observer participant, Adler and Adler, 1988), following them into as many situations as possible whilst seeking to undertake observations that would not disrupt their learning. Observations were recorded in field notes along with other data such as 'conversations with a purpose' 
(Burgess, 1984). These conversations with the participants took place during break times, when they were asked to explain further their actions or to reflect on what had just been observed. Other forms of data included emails from the delegates, visual depictions of their learning, reflective presentations of their experiences and written stories on the impact of the learning on their companies. Additionally, unstructured qualitative interviews were carried out with participants in their place of work, focusing on how they thought they were learning. Along with these data sources, a reflective diary was kept by [first author] to create 'thick description' (Geertz, 1973) of the events.

\section{Data analysis}

Through our approach to data analysis we sought to challenge the underlying assumptions that had shaped our pedagogic approach in the Programme from which the data was drawn - looking awry (Western, 2008) at our taken-for-granted assumptions regarding transformative learning as a good thing. Of significance was how to separate [first author] from her situated understanding of the data; [First author] had been part of the intersubjective experiences within the data (Finlay and Gough, 2003). This point is neatly captured by Stanley and Wise as 'agent(s) of research whose own sel[ves] and experience[s] cannot be left behind' (1993: 6). Such active presence in the data analysis moved us towards aesthetic auto-ethnography (Ellis, Adams and Bochner, 2011). The aesthetic auto-ethnography sought to illuminate aspects of care ethics in the Programme from [first author's] experience by 'describ[ing] stor[ies] of [this] experience - how it is used, understood, and responded to for and by [her] and others' (Ellis, Adams and Bochner, 2011: 282). Anchored to intersubjectivism and situated within a 'social dialogical context' (Tanggaard, 2009: 1498), we sought to engage in a structured process of reflexivity - a form of co-constructed auto-ethnography (Parry and Boyle, 2009). Kempster and Stewart (2010: 210) have argued that co-constructed auto-ethnography is a 
suitable approach to stimulate a hyper-reflexive stance and trigger deep self-disclosure from 'a conscious experiencing of the self as both inquirer and respondent', through the prompt of an outsider (in this case [second author]). The reframing of the data thus occurred as a continuous back-and-forth intersubjective reflexive dialogue of understanding 'through interpretive procedures [and] a reciprocity of perspectives' (Cunliffe, 2011: 657).

The co-constructed auto-ethnographic process had two distinct stages: first, we both engaged in an iterative, intuitive and fluid process (Cunliffe, 2011) of immersion in the data, reading extant literature focused on care ethics within peer-learning communities and discussing the issues and themes between the two of us. We established two questions that guided the second stage: is transformative learning an ethically good thing? Is care ethics in tension with transformative learning? The second stage entailed [second author] in questioning, probing and interpreting [first author]'s emerging reflexive appreciation of her experiences. There were three face-to-face meetings to develop the reflexivity on the experiences and data. Each meeting was summarised by both authors, creating notes on the emerging insights. Eventually, the notes formed a shared understanding of the implications of care ethics related to the pursuance of transformative learning within the Programme captured as a tension between an emancipatory agenda and care ethics within management education.

In order to give a rich sense of verisimilitude of this understanding, we established three representative narratives. These accounts are based on real events that occurred during the Programme, combining ethnographic observations, interviews, general conversations, emails and online forum posts. Drawing on Czarniawska (1997), the three narratives serve as reframed representations of our interpretation of the ethical tension between transformative learning and care ethics. This tension can be encapsulated as: 
cheating the process as ethical resistance; coercion to assert the greater good of transformative learning; and confessional tale of relational impact of transformative learning. The three narratives reflect an embodied appreciation of the data: an authentic yet new understanding of what we had not previously appreciated. Accordingly, they give insight to, and capture the essence of, our intersubjective (re)interpretation of our data. Any use of metaphor can help reveal insight from the data but metaphor can also obscure access to alternative insights (Lakoff and Johnson, 1980). The selectivity of the three metaphors thus requires some elaboration. It was during the second stage - the crafting of the auto-ethnographic account - after [first author] had established three narratives, that [second author] generated an interpretation of each narrative through a number of metaphors. At the next meeting we discussed the metaphors in terms of which metaphor seemed to capture the verisimilitude of the aesthetic auto-ethnography of the experience. We settled readily on the respective metaphor for each narrative. The ease by which this occurred perhaps reflects the intersubjective shared experience as facilitators of the Programme. However, if a third author, from outside the shared experience, had been part of the team, maybe a different set of metaphors and subsequent interpretation might have emerged.

We do not seek to generalise from our co-constructed auto-ethnography. It is neither the typicality nor the representativeness of the three narratives that is significant; this would be in tension with aesthetic auto-ethnography, whose remit is 'understanding subjective meanings as the basis of social action' (Rees and Gatenby, 2014: 135). Rather, we offer an insight into the tensions within management education - presented by the narratives - between an ethic of pursuing emancipatory potential and care ethics, along with the emerging theoretical reasoning, that we offer. 


\section{Findings}

We present three narratives that highlight the interplay and tensions between the educator and the delegates placed within a pedagogy in the pursuit of transformative learning. The first narrative highlights the theme of 'cheating' and exposes the aspired behaviours of action learning (AL) as a mechanism for transformative learning; it also demonstrates the tactics adopted by delegates to negate them. The second highlights the notion of coercion in the pursuance of transformative learning, looking back at the facilitator's coercive behaviour within an experiential activity. The over-riding ethic of pursuing transformative learning is analysed to give insight into the tension between transformative learning and care ethics. The third narrative highlights a 'confession' and tells the story of the role of transformative learning in a delegate's departure from the family business and her husband. Each narrative is contextualised with why the Programme used certain learning interventions to aid transformative learning; and each examines the question as to whose interest is being served by such learning.

\section{Ethical resistance: Cheating the process}

AL has long been understood as a transformative learning process (Dilworth and Willis, 1999), and is underpinned with critical dialogue. Here, the AL set is a space for the ownermanagers to talk to one another in confidence and learn how to come to actions/resolutions through the process of open questions and reflection, followed by action (Revans, 1980). Each set had an experienced facilitator, who sought to guide (and control) them on how to help one another through the process of open questions.

The following narrative account is of the third AL set meeting, of a total of six throughout the Programme, each lasting half a day.

The seven set members are settled in a circle on the red, comfy chairs. I am the facilitator. They are all looking at Frances as she presents her issue; some set members ask open 
questions in an attempt at helping Frances think about her issue. This doesn't seem to be helping, though. Gaynor puts her pen in front of her to indicate she wants to chip in and says she wants to make an 'observation', as she puts it, and suggests an action for Frances. I have noticed they have begun using the term 'observation' to cover up what they are really doing, which is giving advice. Gaynor has just told Frances what to do; this is exactly the opposite of what she should be doing using the AL approach.

At the first AL set meeting I helped them to set their own ground rules, which explicitly stated they would not give each other advice. I want them to help each other; I want Frances to reach an appropriate resolution to her issue, but I want them to do it through the process of $A L$, asking open and insightful questions. I feel torn between letting Gaynor carry on with her 'observation' and wanting to step in and encourage her to help Frances via the AL approach. This internal struggle is making me feel uncomfortable, I want them to 'do' AL. I step in. I ask Gaynor if she can rephrase what she has just said and think of some questions that would help Frances, as opposed to telling her what to do. Gaynor has broken a ground rule, she knows she has, she looks at me sheepishly and with a smile says, 'I just want to tell her what to do.' At this point, another set member, Colin, says, 'Well, yeah we're all thinking that but you have to ask a question.' The whole set laughs, which I take to mean they are complicit in wanting to give advice.

Later on, Adam says he doesn't feel he is getting anywhere with his issue and he wants suggestions. He shuffles back in his seat, sighs and says, 'Will you just tell me what to do?' Earlier on, he had been extolling the benefits of open questions and now he is asking the group for explicit advice. He laughs a little and winks at me, presumably acknowledging that this isn't what the AL set should do. Gaynor immediately says with a wry smile, 'We're not allowed to do that, remember the ground rules' and, at the same 
time, Colin says, 'We don't do that here, we're not allowed to tell you.' Adam chuckles and says, 'You can cheat!' and winks again. I feel them all looking at me to guide them on whether they can have a free-for-all and tell Adam what to do, or whether I am going to make them stick to the AL process. Gaynor has said previously that it is like them needing to take their medicine. I want them to take their medicine of asking open questions and I feel this will help them; I have seen it help in the long-term. So, I stick with the approach and set about an activity which focuses on the art of open questions.

On one level, the dilemma is whether to persist with the desired open questions or allow a migration to giving advice. On another level, it is about the pursuit of transformative learning. Indeed, AL was used in the Programme for this purpose and [first author] was pursuing this goal. Re-examining this narrative, we reflected on what might have occurred if suggestions had been offered. Would these have been tailored to immediate pragmatic needs? The scope of the impact might have been much less in a relational sense. The issue holders, Frances and Adam, were seeking a way forward and the advice could have been just what was needed. A care-ethic orientation would be towards cohesion. The multiple voices being heard in this narrative were initially seen by us as cheating the process. The insistence on pursuing AL was potentially fracturing the group cohesion. On reflection, the attempts to subvert the process by breaking the AL rules may have reflected a form of ethical resistance to a pedagogy that possibly appeared to the participants as uncertain and disruptive. Using the tactic of 'observations', to give advice to sidestep the use of questions, is a form of care ethic to help and sustain cohesion. A colleague is seeking advice and her peers have insight to help her. The participants were offering technical and tactical solutions to the everyday problem.

Connecting this narrative to Cunliffe's (2008) notion of a relationally responsive orientation we can see how the participants were engaged in a moment of dialogue that 
sought, mutually, to shape new insights not just for the various 'issue holders' but intersubjectively for all the participants - i.e. coming to know themselves through others. The care ethic of connectedness and minimisation of relational harm is to draw out the collective moral responsibility to think more reflexively about ourselves with others. If the good thing is reframed towards minimising hurt and enriching connectedness, as well as attention to relationships impacted within and beyond the Programme, a tension develops. This tension is between the pursuance of transformative learning and the associated emancipatory agenda, as a morally good thing for the individual and the pursuance of a care ethic towards the relational good as an intersubjective relationship. [Co-author] pursued the pedagogic assumption that advice would limit the emancipatory potential emergent from the AL process intended, in time, to expose challenges to personal underlying assumptions. Yet by aligning Cunliffe's notion of intersubjectivity - as relationally responsive knowing through dialogue - with care ethics, we can appreciate the intuitive and embodied sense of the group's resistance to [first author]'s pursuance of individual transformative learning.

The narrative illustrates a perspective that the pursuit of transformative learning as a morally good thing is potentially in tension with care ethics. The next narrative pursues this tension.

\section{Coercion to assert the greater good of transformative learning: Please come out of the}

\section{toilet}

The following account is from [first author]'s reflective diary reflecting on an incident from the beginning of the Programme, when the delegates are on a two-day, overnight event. It is the first time they have all met each other save for the introduction day. Facilitated exercises take place over the duration, with discussion and reflection after each to contextualise their learning and stimulate critical reflection on the owner-manager's 
pivotal roles in their businesses. The exercises are designed to provoke emotional responses through intensive experiential learning (Kolb and Fry, 1975).

Billy proved very challenging this morning. We were doing the human chessboard exercise, in which the delegates are asked to assume certain character roles. Billy was a worker, normally the most enjoyable role, where they really do get into character and wreak (harmless) havoc. Four workers are standing on the life-size chessboard outside in the cold and the only communication they have with the managers - who sit in the warmth inside - is through another character, the supervisor, who has a walkie-talkie. The workers are to await instruction, and the idea is that they become frustrated, bored and annoyed with the managers. This is a crucial part of the exercise, as afterwards we unpick it and explore the feelings from the different perspectives, then link this back to their own businesses. It is a delicate exercise and one which requires careful facilitation; the workers need to be provoked a little, but not too much.

Billy was getting increasingly agitated, and I kept asking him to stay on his square, as this was part of the exercise. He kept turning to his fellow workers and complaining that people didn't know what they were doing. I asked him to 'trust-the-process', but he said huffily that he'd had enough, kicked one of the plastic discs and stormed off, walking at speed towards the building where the managers were, about 20 metres away. The other three workers looked at me and asked whether this was part of the game: it was not. I was concerned about Billy but equally annoyed by his disruptive behaviour. He left at a critical point in the exercise and I felt we were in danger of undermining the learning and the discussion session to follow. I decided I couldn't risk Billy finding the managers and, although I didn't want to leave the other workers, I went to find him. I asked the other workers to stay on the chessboard. 
On my way, I bumped into [other facilitator] and asked if she had seen Billy. She had; he had gone to the toilets. The male toilets were just down the corridor, so I hastily went there and stood outside the main door, looking at the male sign. After more time than I would have liked, I tentatively knocked on the door: no answer. I knocked again and called out softly, 'Billy?' Again, no answer. This was such an awkward moment. Eventually, the door opened and Billy looked at me with an exasperated expression. A whole load of emotions flowed through me. I wanted the delegates to have the lightbulb moment I had seen hundreds of times before with this activity, and Billy was jeopardising it. I was annoyed. He was taking me away from the whole group. Equally, I wanted to check he was okay and give him the chance to talk things through. Billy looked at me and said in a pleading tone, 'You've got to help me here, I'm an engineer, show me the evidence. Why does this stuff supposedly work?'

Here we have a narrative of educator power in which the educator sought to pursue what she felt was right. Carrying out the exercise as planned was in the interest of the cohort as a valuable stimulant to the reflexive dialogue that would follow. The exercise generates much tension between the participants both during the exercise and afterwards. Yet, [co-author] knows that, repeatedly, the exercise is a significant mechanism for achieving the Programme aim of engendering transformative learning. Such approaches are undoubtedly most common to experiential learning (Gilmore and Anderson, 2011). The ethical base is consequentialist - the end justifies the means. Viewed through the lens of care ethics, the exercise is problematic. The narrative illustrates a low priority for the care of the individual, and for relational tensions that became manifest through the exercise. Billy removed himself from the group because of his anxiety. He was pursued to a toilet to persuade him to re-join the exercise - the argument being he is damaging the process for him and his colleagues in terms of the Programme aims. On emerging from the 
toilet, Billy expressed discomfort about the learning processes. From the perspective of care ethics, there was clear hurt occurring. Furthermore, he had detached from the group. Connectedness with his colleagues, and indeed with the [co-author], was under stress.

The chessboard exercise seeks to stimulate reflexivity through discomfort and Billy was an unfortunate casualty of such discomfort. The exercise requires careful facilitation to bring the cohort back to a connected whole. In major part, [first author] was concerned about how such connectedness would now be re-established. Power was brought to bear to limit the damage. The incident with Billy was an extreme outcome of the exercise; but the purpose was to provoke and stimulate questions of taken-for-granted assumptions surrounding management. We now question the ethics of this exercise, despite its significance to the Programme. The learners had been advised to 'trust the process'. Yet there had been no discussion about the ethics of transformative learning and the range of possibilities this could make manifest. Neither had there been a conversation about the emotions that could be engendered, or the impact on relationships. There had been no conversation about the role of the facilitators and the power used to generate such emotional impact. Rather, the assumption we made was that engendering transformative learning is a good thing, and that ethical justification gave us wide discretion in designing a pedagogy to achieve those ends. This then is the educator's tyranny that we now see in our practice.

If educators do not question their ethical assumptions of transformative learning, and the power to enable the same, this is surely a form of educational tyranny. The consequence of this tyranny is the justification of the pursuance of the emancipatory goal as the higher order good, and this negates attention to care ethics. The exercise generated vulnerability; hurt, disconnection, and voices were suppressed. During the exercise and in the review the educator tyranny was manifest through unequal relationships and power 
asymmetries. Slowly, in the review, some participants began to understand the purpose of the exercise, but repeatedly a few were left dislocated and emotional. The embodied question Billy asked, 'Why does this stuff supposedly work?' captures the essence of dislocation between educator and participant. The comment that we have both used to learners on the Programme of 'trust the process' is perhaps unethical in terms of care ethics. The opaque nature of the pedagogy, which is not explored with learners because it risks taking away the transformative potential, has the very real danger of emotional disturbance and relational disruption. Drawing again on Cunliffe's central ontological argument of intersubjectivity and how 'our lives are interwoven' gives salience to the moral responsibility to the interwoven relationship between the participants and also between participants and educators. The key issue for us as educators is the need to balance the pursuit of transformative learning with such relational moral responsibility.

The final narrative extends the discussion of care ethics beyond the bounds of the Programme - to the relationships affected by transformative learning.

\section{Confessional tale of relational impact of transformative learning: Leaving the business, leaving the husband}

During the Programme there are four dedicated structured sessions, called 'learning and reflection days', which provide a forum for the delegates to come together to reflect on their learning and to discuss and plan actions. The following account is from [first author]'s reflective diary on the final learning and reflection day (month 10):

I commenced the session by giving out their original application forms to join the Programme. There is some laughter from one table and I hear a gasp from somewhere else in the room. After a few minutes they all start talking and some are sharing their application forms. I stand up and speak loudly over the noise and ask, 'How do you feel 
now you have seen those?' There is much discussion about looking back at themselves all those months ago. Maggie comments, 'I'm a completely different person now.'

That night, on the forum, I post a question to get them talking about what their plans are for the future of their businesses. This prompts discussion: many delegates are online at the same time, typing in replies telling each other what they want to achieve. Maggie joins in with more of a personal tone, writing, 'I think you all know what a tough time I've had of late and I'd like to thank you all for your support.' She continues, 'I'm in the process of setting up another [type of] business. [Husband] was the main breadwinner so I can't afford not to work and I love what I do. I'd like to stay in touch with you all, I might be back to square one but it's not the same!' Maggie had joined the family business with her husband. But a couple of months' ago, she split up with her husband and she left the business. Maggie comments, 'I feel it is important for you to know where I'm coming from. I came into the business for the wrong reasons, ... It's been a huge learning curve and hearing what you do in your businesses has helped enormously. I have taken a huge step and will be leaving the family business. I will now start to do things which suit me and not everybody else, ...this is tied up with leaving [husband] too. Although this may sound sad from the point of view of the family unit, for me this is a rather large and hopefully a very useful step forward.'

The Programme appears to have generated transformative learning that has led to significant impacts on Maggie's relationships in the business and to the family. The scope of relational impact as a consequence of the Programme has been considerable. Maggie's final comment points to the anticipation of not knowing where this might lead. Emancipatory development has consequences. We are not suggesting that we, as educators, have the right to limit such; but equally, do we have the right to instigate the same without consideration of care ethics for deliberately designing a transformative 
pedagogy? In essence, Maggie's narrative points to the need to involve learners in a dialogue about the potential relational consequences of a pedagogy that seeks transformative learning. The comments by Maggie, of her surprise at becoming a different person, allude to limitation both in her understanding of the change and indeed in her control of the change. There is a sense that transformative learning creeps up on the blind side. Arguably, we should have given attention to the need for participants to understand the action and the learning that was occurring within the Programme and engage more deliberately in an appropriate dialogue. For example, we have not sought to create ongoing dialogue that gives attention to how our selves are developed in relation to others: 'the whole parts of our life are part of the life of others' (Cunliffe 2008: 129). There was a strong sense of this when Maggie commented: 'hearing what you do in your businesses has helped enormously.' Through the dialogue, her relational knowing had 'shape[d] [her] understanding of possible worlds, of ways of orienting [herself] in these possible worlds and of new ways of being and acting' (2008: 130).

Through analysing this narrative, we have come to realise that we had a duty of care to initiate dialogue that enabled participants to appreciate the potential impact of the emerging transformative learning on the relationships in which they are situated. In this way, educators would seek to make overt and conscious an orientation to care ethics, both within the Programme community and to communities beyond the Programme.

The intersubjective dynamic of care ethics connects strongly to reflexive dialogue. We suggest that connecting these two elements may give helpful insight as to how transformative pedagogy and an emancipatory agenda can be recalibrated to remain an ethically 'good thing'. We explore this next within our discussion.

\section{Discussion}


In whose interest is transformative learning? This question seems to offer an axiomatic answer: the learner. There is an assumption that it is a good thing for learners to 'reconstruct basic assumptions and expectations that frame thinking, feeling and acting' (Laros at el, 2017: ix). The implications of this are significant. The reach and impact on a range of relationships may be considerable. It is understandable that a learner should have the choice and opportunity to undertake this process, but the consequences and repercussions impact on many people. Is transformative learning in the interests of these people? Within debates on ME and CME the duty of care and to do no harm is not prominent. Yet it is clear through our research that there is much potential to do harm in the form of damaging relational cohesion. In the context of the pivotal role of an ownermanager, the impact on the SME broadens out the relational care requirement to a set of stakeholders likely to be impacted by transformative learning - people connected to the owner-manager, such as the employees, owners and families. Many of these people would not be party to conversations with regard to participating in the Programme.

We extend Fenwick's (2005: 33) most pertinent question: 'How can an educator ethically justify such radical intervention in others' beliefs, identities and values?' when there are likely relational implications? It does not seem sufficient to us that educators can frame their ethic of intervention by seeking 'to help men and women realise and enjoy their truly human capabilities' (Brookfield, 2002: 273) whilst standing outside relational considerations. This might mean - and the example of Maggie speaks to this - that an owner-manager decides that the business is not the vehicle for achieving her/his discovered purposes and decides to close or sell the business and break up relationships. Can the care ethics implications of this be bracketed out from consideration by the educators? We suggest it should not be. 
As we have asserted, we do not think educators can act in either: an amoral manner and suggest the consequences of developing transformative learning in learners is beyond the responsibilities of educators; or, take the moral high ground of engendering a broad utopian vision of learners as 'transforming the social world through understanding and questioning' (Reynolds, 1999: 173). Educators have a moral responsibility in how they design and implement pedagogies that seek emancipatory potential, but this needs to be rooted in the complexity of learners' relational and contextual detail (Fenwick, 2005). Aligned with care ethics, we have drawn on Cunliffe's intersubjective orientation where 'we are always in relation and responsive to others' (2008: 131); that, therefore, generates a relational responsibility. Cunliffe continues, 'we are always speaking and acting in relation to others ... [and] if we believe we are constantly creating meaning, sense and selves as we relate with others, then we need to reflexively surface and articulate how we create these meanings, so that we can act and interact in more responsive and ethical ways' (2008: 132).

Encouraged by Cunliffe, we are suggesting that educators engaging specifically in transformative learning need to consider engaging in reflexive dialogue. Arising from this, educators must recognise 'that we summon each other in responsibility ... and thus need to examine our fundamental assumptions, values, ways of interacting and how these affect' (Cunliffe, 2008: 132) participants on an educational programme and those they are relationally emplotted. This is our framing and application of Cunliffe's work to care ethics, as this is not given explicit attention by Cunliffe. However, her frame does offer a useful lens through which care ethics can be examined within management education in pursuit of transformative learning. In essence, Cunliffe advocates a moral argument for an emancipatory pedagogy that embraces relational responsibility in order for learners to see 
and act in the world differently 'with and for others (Ricoeur, 1992: 172) [when] our lives are so interwoven' (Cunliffe, 2008: 132).

Thus, there is need to enable a dialogue that leads to alignment around the emergence of a care ethic as a basis for moral understanding and for action. For both critical and non-critical educators such dialogue can make salient the care ethics that a programme pedagogy, oriented to engendering transformative learning, may need to address. We suggest that the taken-for-granted assumption of transformative learning as a good thing should become central to reflexive dialogue for educators. For example, an ethic of care may be an assumed cornerstone; however, do educators examine this assumption in terms of questioning the good thing of emancipatory discovery with regard to the care of the learner and due regard to care of other stakeholders vicariously drawn into the mix (Gabriel, 2009)? Through reflexive dialogue as moral deliberation, questions can be explored, such as: how do educators balance the desire for impact with the implications of impact? Can the scope and target of impact be considered? In essence, in whose interest are the educators acting and for what benefit? The reflexive dialogue should not be restricted to educators. The intersubjective orientation of care ethics speaks loudly to the necessity of embracing learners in an awareness and understanding of the implications of participating in an emancipatory educational agenda. The relational impact should be central to such dialogue. In this way, Cunliffe's intersubjective notion that 'we are always in relation and responsive to others' $(2008: 131)$ is a most helpful central tenet in shaping a participative reflexive pedagogy. Perhaps, through such dialogue, the emancipatory agenda may become a 'flexible pursuit of beautiful consequences' (Brookfield, 2001: 20) - the notion of beautiful we interpret here to embrace a relational appreciation. 
If we look out from management to other disciplines, there are illuminating examples of professions engaging in relational reflexive dialogue and care ethics when considering the question, 'In whose interest?' Social work, counselling and psychotherapy, for example, all have a long history of reflexive dialogic practice as an interactional process that enables practitioners to critically reflect, question and seek guidance to aid professional growth and improve good practice (see, for example, Gray and Lovat, 2007). It does seem striking that these disciplines see the necessity to address this question on a regular basis, yet the field of management learning, and many colleagues who deeply embrace the emancipatory agenda, particularly through transformative learning, paradoxically do not question and engage in reflexive dialogue of the underlying assumption that such an agenda is a good thing. It could well be unsettling for educators to question this underlying assumption; yet this unsettling is in major part the orientation of management education that pursues transformative learning, and as such may give educators greater appreciation and empathy for the experiences they intend for programme participants.

We need to emphasise that our data collection did not follow the owner-managers into their work contexts. This then is a limitation of the research. As a consequence, we suggest there is the need for subsequent research to explore the relational impact of transformative learning upon management practice.

\section{Conclusion}

Our article has sought to bring attention to the shadow side of management education which has been given little attention since Reynolds (1999). The gap we have addressed focuses on ethical considerations associated with pedagogies that seek an emancipatory agenda; and, in particular, the assumption that transformative learning is a good thing. 
Impact is similarly perceived as a good thing. The essence of our examination of the Programme has provoked for us significant reflexivity in this area about our purposes and ethics as management learning educators. We hope our contribution will stimulate debate for both critical management educators and non-critical management educators on this important topic. For UK academics, the discourse on impact has become a dominant and over-riding requirement of research. From a policy perspective, such discourse should embrace a critically reflexive moral dialogue on the understanding of such impact. The impact of the Programme has been heralded as outstanding - indeed a $4 *$ impact case study (in the UK Research Excellence Framework, 2014) was derived from it. In this assessment no account has been taken of the relational impact and the number of divorces across the 3000 plus participants.

\section{References}

Adler PA and Adler P (1988) Observational techniques. In: NK Denzin and YS Lincoln (eds.), Collecting and Interpreting Qualitative Materials (pp. 79-109). London: Sage Publications Inc., Thousand Oaks.

Alvesson M and Wilmott HC (1992) On the idea of emancipation in management and organization studies. Academy of Management Review, 17(3): 432-64.

Barber AE, Wesson MJ, Roberson QM and Taylor MS (1999) A tale of two job markets: Organizational size and its effects on hiring practices and job search behavior. Personnel Psych ology, 52: 841-867.

Barnes S, Kempster S and Smith S (2015) Leading small business: Business growth through leadership development. Cheltenham: Edward Elgar.

Baumgartner L (2001) An update on transformational learning. New Directions for Adult and Continuing Education, 89: 15-24. 
Bell J (1999) Doing Your Research Project: A Guide for First-time Researchers in Education and Social Science, Third Edition, Buckingham, Open University Press Brookfield SD (2000) The concept of critically reflective practice. In A.L. Wilson \& E.R. Hayes (Eds.), Handbook of adult and continuing education (pp. 110-126). San Francisco: Jossey-Bass.

Brookfield S (2001) Repositioning ideology critique in a critical theory of adult education. Adult Education Quarterly, 52(9): 7-22.

Brookfield S D (2002) Reassessing subjectivity, criticality and inclusivity: Marcuse's challenge to adult education. Adult Education Quarterly, 52(4): 265-280.

Bryman A and Bell E (2003) Business Research Methods, Oxford, Oxford University Press. Burgess RG (1984) In the Field: An Introduction to Field Research. London: Allen and Unwin.

Cope J, Kempster S and Parry K (2011) Exploring distributed leadership in the small business context. International Journal of Management Reviews, 13(3): 270-285.

Courtenay BC, Merriam SB, Reeves PM and Baumgartner L (2000) Perspective transformation over time: A two-year follow up study of HIV-Positive adults. Adult Education Quarterly, 50(2): 102-119.

Cranton P and Roy M (2003) When the bottom falls out of the bucket: Toward a holistic perspective on transformative learning. Journal of Transformative Education, 1(2): 86-98.

Cunliffe, AL (2008) Orientations to social constructionism: Relationally responsive social constructionism and its implications for knowledge and learning. Management Learning, 39(2): 123-139.

Cunliffe AL (2011) Crafting qualitative research: Morgan and Smircich 30 years on. Organizational Research Methods, 14(4): 647-673. 
Czarniawska B (1997) Narrating the organisation: Dramas of institutional identity.

Chicago: UCP.

Dilworth RL and Willis VJ (1999) Action Learning for Personal Development and

Transformative Learning, Advances in Developing Human resources, Volume: 1 issue: 2 , page(s): $75-82$

Dunn EL (2011) Towards transformation in management education: Telling the managers' tales. $\mathrm{PhD}$ thesis, Lancaster University.

Ellis CS, Adams TE and Bochner AP (2011) Auto-ethnography: an overview. Historical Social Research, 36(4): 273-90.

Ellsworth E (1989) Why doesn't this feel empowering? Working through the repressive myths of critical pedagogy. Harvard Educational Review, 59(3): 297-324.

Fenwick T (2005) Ethical dilemmas of critical management education. Management Learning, 36(1): 31-48.

Ferreday D and Hodgson V (2008) The tyranny of participation and collaboration in networked learning. Proceedings of the 6th International Conference on Networked Learning.

Finlay L and Gough B (2003) Reflexivity: a practical guide for researchers in health and social sciences. Blackwell Science: Oxford

Freire P (1970) Pedagogy of the oppressed. London: Penguin.

Gabriel Y (2009) Reconciling an ethic of care with critical management pedagogy. Management Learning, 40(4): 379-385.

Geertz, C. (1973) The Interpretation of Cultures: Selected Essays, New York, Basic Books.

Gibb A (2009) Meeting the development needs of owner managed small enterprise: A discussion of the centrality of action learning. Action Learning: Research and Practice 6(3): 209-227. 
Gilligan C (1982) In a different voice: Psychological theory and women's development. Harvard University Press, Cambridge.

Gilligan C (1995) Hearing the difference: Theorizing connection. Hypatia, 10(2): pp. 120127.

Gilmore SE and Anderson VA (2011) Anxiety and experience-based learning in a professional standards context. Management Learning, 43(1): 75-95.

Gray M and Lovat T (2007) Horse and carriage: Why Habermas's discourse ethics gives virtue a praxis. Social Work, Ethics and Social Welfare, 1(3): 310-328.

Held V (2006) The ethics of care: personal, political, and global. Oxford: Oxford University Press.

Hiley D (1987) Power and values in corporate life. Journal of Business Ethics, 6(5): 343353.

Hinman LM (2008) Ethics: A pluralistic approach to moral theory. Belmont, CA: Thomson Higher Education.

Howorth C, Smith S and Parkinson C (2012) Social learning and social entrepreneurship education. Academy of Management Learning and Education, 11(3): 371-389.

Kempster S and Stewart J (2010) Becoming a leader: a co-produced autoethnographic exploration of situated learning of leadership practice. Management Learning, 41(2): 205-19.

Kolb DA and Fry R (1975) Toward an applied theory of experiential learning. In C Cooper (ed.) Theories of Group Process. London: John Wiley.

Lakoff G and Johnson M (1980) Metaphors we live by. Chicago: The University of Chicago Press.

Laros A, Fuhr T and Taylor EW (2017) Transformative learning meets Bildung: An international exchange. Rotterdam: Sense Publishers. 
Larsson M and Holmberg R (2015) It's the organization that is wrong': Learning of conceptual models as a resource for identity work in leadership development program. $17^{\text {th }}$ International Leadership Association Conference, Barcelona, October $14-17^{\text {th }}$.

Metz T and Miller SC (2016) Relational ethics. In H LaFollette (Ed.) The international encyclopaedia of ethics (pp. 1-10). Malden, MA: Blackwell Publishing Ltd.

Mezirow J (1981) A critical theory of adult learning and education. Adult Education, 32(1): 3-24.

Mezirow J (1990) Fostering critical reflection in adulthood. San Francisco: Jossey-Bass.

Mezirow J (2000) Learning as transformation. San Francisco: Jossey-Bass.

Mezirow J (2003) Transformative learning as discourse. Journal of transformative Education, 1(1): 58-63.

Parry KW and Boyle M (2009) Organizational auto-ethnography. In D Buchanan and A Bryman (eds) The sage handbook of organizational research methods (pp. 690702). London: Sage.

Perriton L and Reynolds M (2004) Critical management education: From pedagogy of possibility to pedagogy of refusal? Management Learning, 35: 61-77.

Rees C and Gatenby M (2014) Critical realism and ethnography. In PK Edwards, J O'Mahoney and S Vincent (eds) Studying organizations using critical realism: A practical guide (pp. 132-147). Oxford: Oxford University Press.

Revans R (1980) Action learning: New techniques for management. London: Blond and Briggs.

Reynolds M (1999) Grasping the Nettle: Possibilities and pitfalls of a critical management pedagogy. British Journal of Management, 9: 171-184. 
Reynolds M (2000) Bright lights and the pastoral idyll: Ideas of community underlying management education methodologies. Management Learning, 31(1): 67-81.

Sevenhuijsen, S (1998) Citizenship and the ethics of care: Feminist considerations on justice, morality, and politics. New York: Routledge.

Smith L and Peters S (2006) Leading by design: the case of LEAD. Paper presented at Symposium: Owner-managerial Leadership Learning. Belfast, British Academy of Management.

Spiller C, Erakovic L, Henare M and Pio E (2011) Relational well-being and wealth: Maori businesses and an ethic of care. Journal of Business Ethics, 98: 153-169.

Stanley, L. and Wise, S. (1993) Breaking Out Again: Feminist Ontology and Epistemology, London, Routledge.

Tanggaard L (2009) The research interview as a dialogical context for the production of social life and personal narratives. Qualitative Inquiry, 15(9): 1498-1515.

Taylor EW (2017) Transformative learning theory. In A Laros, T Fuhr and EW Taylor (Eds.). Transformative learning meets Bildung: An international exchange (pp. 1732). Rotterdam: Sense Publishers.

Tisdell E J (2005) Feminism. In L. M. English (Ed.), International encyclopaedia of adult education (pp. 254-257). London: Palgrave.

UK Research Excellence Framework (2014) Stimulating long-term growth in UK SMEs: the $\mathrm{LEAD} \circledast$ programme. Lancaster University Management School, Impact Case. http://impact.ref.ac.uk/CaseStudies/CaseStudy.aspx?Id=43589

Western S (2008) Leadership: A critical text. London: Sage.

Wren C and Jones J (2012) Quantitative evaluation of the LEAD Programme, 2004-11. University of Newcastle Upon Tyne: Newcastle. Available at: http://www.ncl.ac.uk/nubs/research/publication/192709 
Table 1: Biographical information about the research participants (those highlighted are central to the narratives presented in the findings)

\begin{tabular}{|c|c|c|c|c|c|c|}
\hline $\begin{array}{l}\text { Name } \\
\text { (pseudonyms } \\
\text { are used) }\end{array}$ & Sex & Age & $\begin{array}{l}\text { Title } \\
\text { (self- } \\
\text { classified) }\end{array}$ & Sector & $\begin{array}{l}\text { Turno } \\
\text { ver }\end{array}$ & $\begin{array}{l}\text { No. } \\
\text { employees }\end{array}$ \\
\hline * Adam & $\mathrm{M}$ & 48 & $\begin{array}{l}\text { Managing } \\
\text { Director } \\
(\mathrm{MD}) \\
\end{array}$ & Facilities management & $£ 3 m$ & 150 \\
\hline * Billy & $\mathrm{M}$ & 49 & MD & Software engineer & $£ 150 \mathrm{k}$ & 8 \\
\hline * Gaynor & $\mathrm{F}$ & 53 & Owner & Food Manufacturer & $£ 10 \mathrm{~m}$ & 86 \\
\hline * Frances & $\mathrm{F}$ & 33 & Director & Hospitality & $£ 200 \mathrm{k}$ & 36 \\
\hline$*$ Colin & $\mathrm{M}$ & 50 & $\mathrm{MD}$ & Software Development & $£ 1 \mathrm{~m}$ & 20 \\
\hline * Maggie & $\mathrm{F}$ & 44 & Director & Financial Services & $£ 203 k$ & 5 \\
\hline Julie & $\mathrm{F}$ & 32 & Director & Food retail & $£ 200 \mathrm{k}$ & 6 \\
\hline Jez & $\mathrm{M}$ & 36 & Partner & IT & $£ 245 \mathrm{k}$ & 13 \\
\hline Ryan & $\mathrm{M}$ & 27 & Owner & Public relations & $£ 2 \mathrm{~m}$ & 26 \\
\hline Dick & $\mathrm{M}$ & 31 & Director & Recruitment & $£ 7 \mathrm{~m}$ & 38 \\
\hline Daniel & $\mathrm{M}$ & 34 & $\mathrm{MD}$ & Water cooler supplier & $£ 500 \mathrm{k}$ & 9 \\
\hline Saul & $\mathrm{M}$ & 44 & $\mathrm{MD}$ & \multirow{2}{*}{ Power supplier } & \multirow[t]{2}{*}{$£ 3 \mathrm{~m}$} & \multirow[t]{2}{*}{25} \\
\hline James & $\mathrm{M}$ & 34 & Director & & & \\
\hline Robyn & $\mathrm{M}$ & 30 & MD & Refrigeration & $£ 1.1 \mathrm{~m}$ & 14 \\
\hline Mac & $\mathrm{M}$ & 28 & Director & Recruitment & $£ 250 \mathrm{k}$ & 6 \\
\hline Naj & $M$ & 31 & $\begin{array}{l}\text { Managing } \\
\text { Partner }\end{array}$ & Fashion & $£ 2.8 \mathrm{~m}$ & 13 \\
\hline Grant & $\mathrm{M}$ & 51 & Proprietor & Property & $£ 90 \mathrm{k}$ & 6 \\
\hline Julie & $\mathrm{F}$ & 44 & MD & Printing & $£ 150 \mathrm{k}$ & 4 \\
\hline Paddy & M & 52 & MD & Air conditioning & $£ 700 \mathrm{k}$ & 8 \\
\hline Martha & $\mathrm{F}$ & 38 & Director & Telecommunications & $£ 200 \mathrm{k}$ & 4 \\
\hline Den & $\mathrm{M}$ & 35 & Director & Printing & $£ 2 \mathrm{~m}$ & 33 \\
\hline Parker & $\mathrm{M}$ & 47 & $\mathrm{MD}$ & Landscaping & $£ 500 \mathrm{k}$ & 23 \\
\hline Ted & $\mathrm{M}$ & 43 & MD & Animation & $£ 1.5 \mathrm{~m}$ & 25 \\
\hline Damian & $\mathrm{M}$ & 42 & Partner & Financial Services & $£ 480 \mathrm{k}$ & 11 \\
\hline Alan & $\mathrm{M}$ & 50 & $\mathrm{MD}$ & Designers & $£ 1.2 \mathrm{~m}$ & 25 \\
\hline
\end{tabular}

